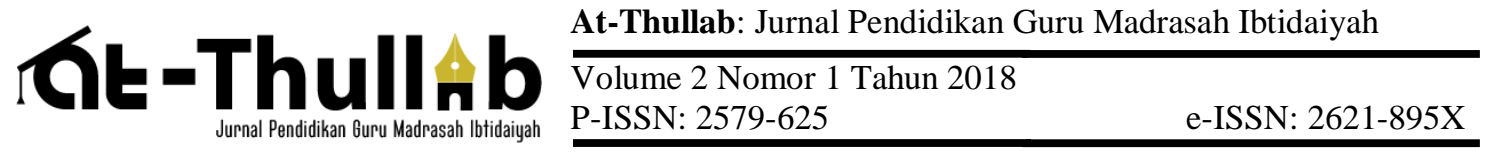

\section{PENERAPAN METODE DEMONSTRASI DAN RESITASI UNTUK MENINGKATKAN MOTIVASI BELAJAR SISWA TERHADAP MATA PELAJARAN FIQH KELAS 2 DI MI DARUL ULUM BOJONEGORO}

\author{
Yulia Pramusinta \\ Universitas Islam Lamongan \\ e-mail: yuliapramusinta@unisla.ac.id
}

\begin{abstract}
Teaching media is a knowledge of the teaching methods used by a teacher or instructor. The method is the method used to achieve the stated goals. Another technique is the presentation technique mastered by the teacher to teach or present learning material to students in the classroom, so that the lesson can be absorbed, understood and utilized by students properly. The better the teaching method, the more effective the achievement of objectives. In reality, the teaching method or method used conveys different information in ways that are used to strengthen students in mastering knowledge, skills and attitudes (cognitive, psychomotor, affective). Specifically the method of teaching in the classroom, the effectiveness of a method is influenced by the goals, student factors, situation factors, and the teacher's own factors. This study aims to determine the effectiveness of the demonstration and recitation methods in increasing student learning motivation in fiqh subjects in class 2 MI. This research is a classroom action research, research instrument using observation sheets and interviews. Data analysis uses a research cycle and is described qualitatively. The results showed an increase in student motivation in fiqh subjects using the method of demonstration and recitation.
\end{abstract}

Keywords: Methode, Demonstration, Resitasi, Motivation Learning

\section{A. Pendahuluan}

Mengajar pada hakikatnya adalah suatu proses, yaitu proses mengatur, proses memberikan, bimbingan atau bantuan kepada anak didik dalam melakukan proses belajar (Nana, 1984). Dalam proses belajar mengajar guru berperan sebagai pendidik dan mengarahkan sedangkan murid berperan sebagai titik pusat dalam pembelajaran, dan agar membuahkan hasil sebagaimana diharapkan, maka baik siswa maupun guru perlu memiliki sikap, kemampuan dan ketrampilan yang mendukung proses belajar mengajar tersebut, untuk mencapai tujuan tertentu. Metode Demonstrasi yaitu metode pengajaran dimana guru atau orang lain sengaja diminta atau murid sendiri memperlihatkan kepada seluruh kelas suatu proses. Sedangkan metode eksperimen adalah metode pengajaran dimana guru dan murid bersama-sama mengerjakan sesuatu sebagai latihan praktis dari apa yang diketahui. Metode demonstrasi adalah suatu metode mengajar yang dilakukan oleh guru atau seseorang lainnya dengan memperlihatkan kepada seluruh kelas tentang suatu proses atau suatu cara melakukan 
sesuatu (Pasaribu, 1986). Teknik resitasi biasanya digunakan dengan tujuan agar siswa memiliki hasil belajar yang mantap karena siswa melaksanakan pelatihan selama melakukan tugas, sehingga pengalaman siswa dalam mengalami situasai dan pengalaman yang berbeda sewaktu menghadapi masalah-masalah baru. Disamping itu untuk memperoleh pengetahuan dari pelaksanaan tugas yang dapat memperluas dan memperkaya pengetahuan serta keterampilan siswa di sekolah, melalui kegiatankegiatan di luar sekolah itu. Dengan kegiatan melaksanakan tugas, siswa aktif belajar dan merasa terangsang untuk meningkatkan belajar yang lebih baik, memupuk inisiatif dan berani bertanggung jawab. Banyak tugas yang harus dikerjakan siswa, diharapkan mampu menyadarkan siswa untuk selalu memanfaatkan waktu sesunguhnya untuk melakukan hal-hal yang menunjang belajarnya dengan mengisi kegiatan-kegiatan yang berguna dan konstruktif. Yang dimaksud dengan metode resitasi atau penugasan adalah metode penyajian bahan dimana guru memberikan tugas tertentu agar siswa melakukan kegiatan belajar, yang mana kegiatan itu dapat dilakukan di dalam kelas, di halaman sekolah, di laboratorium, di perpustakaan, di rumah ataupun dimana saja asal tugas itu dapat di selasaikan (Zuhairini, 1983).

Dalam pemberian metode tugas atau resitasi ini supaya bisa sesuai dengan yang diinginkan maka ada beberapa syarat yang harus diketahui oleh pendidik dan anak didik yang diberi tugas, yaitu: (Zakiyah, 2000) (1) Tugas yang diberikan harus berkaitan dengan pelajaran yang telah mereka pelajari, sehingga murid di samping sanggup mengerjakan juga sanggup menghubungkan dengan pelajaran-pelajaran tertentu, (2) Guru harus dapat mengukur dan memperkirakan bahwa tugas yang diberikan kepada siswa akan dapat dilaksanakannya karena sesuai dengan kesanggupan dan kecerdasan yang dimilikinya, (3) Guru harus menanamkan kesadaran murid bahwa tugas yang diberikan pada siswa akan dikerjakan atas kesadaran sendiri yang timbul dari hati sanubarinya, (4) Jenis tugas yang diberikan harus benar-benar dimengerti sehingga murid tidak ada keraguan dalam mengerjakannya

Dalam mendukung proses pembelajaran diperlukan upaya dalam menumbuhkan motovasi siswa. Motivasi dapat juga dapat dikatakan serangkaian usaha untuk menyediakan kondisi-kondisi tertentu, sehingga seseorang mau dan ingin melakukan sesuatu, dalam kegiatan belajar mengajar motivasi dapat dikatakan sebagai keseluruhan daya penggerak dalam diri siswa untuk menimbulkan kegiatan belajar, sehingga tujuan yang dikehendaki dapat tercapai.

Tugas guru adalah membangkitkan motivasi anak, sehingga ia mau melakukan belajar. Motivasi dapat tumbuh dari dalam diri individu (instrinsik) dan dapat pula timbul akibat pengaruh dari luar dirinya (eksternal). Jenis motivasi ini timbul sebagai akibat dari dalam diri individu sendiri tanpa ada paksaan dan dorongan dari orang lain, tetapi atas kemauan sendiri. Dalam belajar terkandung tujuan menambah pengetahuan. 
Motivasi ekstrinsik timbul sebagai akibat pengaruh dari luar diri individu. Apakah karena adanya ajakan, suruhan, paksaan dari orang lain sehingga dengan kondisi yang demikian akhirnya ia mau melakukan sesuatu atau belajar. Untuk dapat membangkitkan motivasi belajar siswa, guru hendaknya berusaha dengan berbagai cara. Berikut ini ada beberapa cara membangkitkan motivasi ekstrinsik dalam rangka menumbuhkan motivasi intrinsik (Uzer, 1992) (1) Kompetisi (persaingan, guru berusaha menciptakan persaingan diantara siswanya untuk meningkatkan prestasi belajar), (2) Pace making, pada awal KBM guru hendaknya menyampaikan trik pada siswa. (3) Tujuan yang jelas untuk mencapai pembelajaran. (4) Mengadakan penilaian/tes, pada umumnya siswa mau belajar dengan tujuan mendapat nilai yang baik.

Sebagai salah satu komponen pengajaran, metode menempati peranan yang tidak kalah pentingnya dari komponen lain dalam kegiatan belajar mengajar. Tidak ada satupun kegiatan belajar mengajar yang tidak menggunakan metode pengajaran. Ini berarti guru memahami benar kedudukan metode sebagai alat motivasi intrinsik dalam kegiatan belajar mengajar. Motivasi intrinsik adalah motif-motif yang aktif dan berfungsi sebagai alat perangsang dari luar yang dapat membangkitkan belajar seseorang. Dalam penggunaan metode terkadang guru harus menyesuaikan dengan kondisi dan suasana kelas. Jumlah anak mempengaruhi penggunaan metode. Tujuan intruksional adalah pedoman yang mutlak dalam pemilihan metode. Dalam perumusan tujuan, guru perlu merumuskannya dengan jelas dan dapat diukur. Dengan begitu, mudahlah bagi guru untuk menentukan metode yang bagaimana yang dipilih guna menunjang pencapaian tujuan yang telah dirumuskan tersebut (Sardiman, 1986).

\section{B. Metode}

Penelitian ini merupakan penelitan PTK (penelitian tindakan kelas). Penelitian PTK merupakan penelitian praktis yang dimaksudkan untuk memperbaiki pembelajaran di kelas. Penelitian ini merupakan salah satu upaya guru atau praktisi dalam bentuk berbagai kegiatan yang dilakukan untuk memperbaiki dan atau meningkatkan mutu pembelajaran di kelas. PTK dapat diartikan sebagai proses pengkajian masalah pembelajaran di dalam kelas melalui refleksi diri dalam upaya untuk memecahkan masalah tersebut dengan cara melakukan berbagai tindakan yang terencana dalam situasi nyata serta menganalisis setiap pengaruh dari perlakuan tersebut (Sanjaya dan Wina, 2016). Waktu penelitian dilaksanakan pada bulan januari-februari 2016 di MI Darul Ulum Bojonegoro. Subyek penelitian ini adalah siswa-siswi kelas 2 MI Darul Ulum Bojonegoro sebanyak 20 siswa pada semester 2 yang menempuh mata pelajaran Fiqh. Instrumen yang digunakan dalam penelitian ini adalah lembar observasi dan interview. Tehnik analisis data menggunakan siklus penelitian yang terdiri dari siklus pertama dan siklus kedua kemuadian diseskripsikan secara kualitatif. 


\section{Hasil dan Pembahasan}

\section{Siklus Pertama}

\section{1) Perencanaan}

Untuk memotifasi efektifitas dan pemahaman siswa dalam pembelajaran fiqih dan memupuk kesadarannya peneliti menggunakan demonstrasi dalam materi, Tanya jawab materi, Hafalan materi, Resitasi dalam LKS.

\section{2) Tindakan}

Dalam tindakan Siklus pertama ini peneliti membagi menjadi 2 kali pertemuan:

\section{Pertemuan 1}

Dalam pertemuan pertama pelajaran yang ke IV (08.45-09.25) ini peneliti sedikit mengarahkan siswa dan siswi untuk faham dan sedikit tanya jawab akan materi dan mengetahui gunanya pelajaran itu yang mengakibatkan mereka terpupuk kesadaran dalam hati mereka karena dalam pertemuan sebelumnya sudah disampaikan oleh guru pamong, kemudian pendidik menyuruh mereka untuk menghafalkan do'a-do'a sujud syukur, tilawah dan sahwi, yang kemudian peneliti menyuruh mereka setoran sujud sahwi ketika itu juga karena itu merupakan do'a yang paling pendek ketika istirahat kemudian jam pelajaran yang ke V (09.40-10.15) peneliti menyimak hafalan mereka satu persatu, setelah itu peneliti memberikan untuk menghafalkan do'a-do'a lainnya, yang kemudian setoran hafalannya akan di tagih ketika pertemuan selanjutnya.

\section{Pertemuan II}

Dalam pertemuan pertama pelajaran yang ke IV ini peneliti memberikan appersepsi tentang materi apa yang telah disampaikan kemarin dengan tanya jawab kepada murid kemudian peneliti mengidentifikasi dalam materi dan menyampaikan materi yang harus dicapai, kemudian siswa disuruh setoran satu persatu kedepan guru hal ini bertujuan untuk memberiakan motivasi siswa dan menghilangkan kejenuhan dengan adanya wajah yang baru tentang tugas kemarin yang telah diberiakan untuk dihafal, kemudian pelajaran yang ke $\mathrm{V}$ seluruh siswa di ajak ke teras masjid untuk dibimbing dan diberiakan arahan dalam masalah prakteknya, kemudian siswa disuruh untuk mempraktekkannya, setelah itu peneliti memberikan tugas untuk mengerjakan LKS dalam satu bab itu sampai selesai yang kemudian dalam pertemuan selanjutnya akan dikumpulkan oleh peneliti.

\section{3) Pengamatan}

Dalam pertemuan pertama peneliti mendapat gambaran bahwa dalam pembelajaran fiqih ini perlu adanya metode untuk meningkatkan pemahaman siswa dalam materi yang di harapkan untuk menyadarkan mereka pentingnya ilmu fiqih ini. 
Hasil observasi di lapangan menunjukkan bahwa kegiatan pembelajaran bahwasanya telah sesuai dengan apa yang direncanakan, terlibat dengan adanya motivasi yang tinggi dari siswa yaitu dengan adanya praktek setoran hafalan do'a satu persatu dalam materi dan antusias mereka dalam mendemonstrasikan materi yang telah disampaikan, meskipun ada sebagian sekitar lima anak yang belum hafalan yang dua dikarenakan tidak masuk dan yang tiga karena belum lancar membaca al-qur'an dan ada juga yang tidak ikut praktek dikarenakan mereka punya udzur.

\section{4) Refleksi}

Hasil observasi di lapangan dapat disimpulkan bahwa pelaksanaan kegiatan pembelajaran telah berjalan sesuai dengan baik terdapat adanya motivasi yang tinggi dari siswa untuk menghafal bacaan do'a-do'a dalam materi, meskipun diantaranya juga banyak siswa yang belum hafal dikarenakan mereka belum lancar membaca arab dan masih baru menghafalkan, tetapi mereka juga masih berusaha dengan bukti mereka setoran hafalannya diluar jam pelajaran, dan dalam penerapan mengerjakan LKS meskipun dalam pertemuan yang pertama siswa tidak dianjurkan untuk mengumpulkan, tetapi sebagian besar mereka sudah banyak yang mengerjakan.

\section{Siklus Kedua}

\section{1) Perencanaan}

Siklus kedua ini merupakan tahap perbaikan dari siklus yang pertama, untuk memantapkan siswa dalam pembelajarannya, peneliti mengunakan metode demontrasi, tanya jawab, resitasi disamping LKS juga resitasi dalam bentuk skema.

\section{2) Tindakan}

Dalam tindakan Siklus pertama ini peneliti juga membagi menjadi 2 kali pertemuan:

\section{Pertemuan I}

Pada siklus ke-2 pertemuan yang pertama jam ke IV ini peneliti melakukan Appersepsi, kemudian peneliti menjelaskan materi Dzikir dan Do'a dengan dibantu siswa membaca sedikit demi sedikit bergantian supaya siswa antusias semua dalam pembelajaran, sekaligus memberikan contoh dalam bentuk skema dalam penyampaian materinya, kemudian peneliti memberikan sedikit cerita yang berhubungan dengan materi yang diharapkan dapat memupuk kesadaran siswa dalam pentingnya berdzikir dan berdo'a, kemudian peneliti melakukan tanya jawab tentang materi yang ada, setelah itu peneliti membagikan rangkuman dzikir kepada siswa kemudian dibaca bersamasama dan manganjurkan untuk dihafal atau dibaca setelah sholat fardhu, setelah itu peneliti memberikan resitasi dalam bentuk skema yang kemudian untuk pertemuan selanjutnya dikumpulkan, dan sebelum bel istirahat berbunyi siswa diberitahu bahwa nanti ketika jam pelajaran yang ke $\mathrm{V}$ akan diadakan Ulangan Harian dengan tujuan sejauh mana siswa itu menyerap materi yang telah disampaikan dan LKS nya 
dikumpulkan. Ketika pelajaran yang ke V peneliti memberitahu cara menjawab soal ulangan harian dan memberitahu tentang pantangan-pantangan dalam Ulangan harian itu, kemudian peneliti mengambil dan mengumpulkan LKS dari semua siwa, setelah itu peneliti menyurh siswa untuk membagikan soa'l Ulangan harian itu yang kemudian untuk dikerjakan dengan dipantau oleh peneliti, setelah bel berbunyi peneliti mengambil jawaban ulangan harian itu dan mengingatkan kembali akan tugas Resitasi skema itu.

\section{Pertemuan II}

Dalam pertemuan kedua jam ke IV ini peneliti melakukan Appersepsi, kemudian mengidentifikasi masalah dalam materi, setelah itu peneliti membagikan LKS-nya sekaligus memberikan penguatan dengan dibacakanya nialai yang tertinggi dan menyuruh siswa untuk mengumpulkan tugas Skemanya, setelah itu peneliti membahas sedikit lagi tentang tugas skema materi Do'a dan dzikir guna memantabkan pemahaman siswa tentang materi yang telah disampaikan, peneliti juga melakukan tanya jawab kepada siswa guna mengetahui antusias siswa dalam pembelajaran. Kemudian ketiak pelajaran yang ke V guru membagikan so'al Ulangan harian yang kedua dengan materi dzikir dan do'a, yang kemudian dijawab dan dikumpulkan oleh peneliti, setelah itu peneliti memberikan resitasi LKS bab II.

\section{3) Pengamatan}

Hasil observasi dilapangan menunjukkan pelaksanaan pembelajaran pada dasarnya telah berjalan sesuai dengan apa yang direncanakan, ini terlihat dengan adanya motivasi yang tinggi bagi siswa dalam pemahamannya terhadap materi pelajaran dan dari hasil LKS dan Ulangan Harian yang memuaskan. Dan dengan adanya Resitasi dalam bentuk skema siswa akan lebih mudah menyerap pelajaran, terbukti ketiak dilakukan Appersepsi dan tanya jawab rata-rata dari siswa bisa menjawabnya dengan benar.

\section{4) Refleksi}

Dari pengamatan siklus yang ke-2 ini, siswa kelas 2 sudah cukup baik dalam penerapan metode demonstrasi dan resitasi, karena mereka sudah bisa memparaktekkan materi yang telah disampaikan dan meraka juga sudah menunjukkan tes uji kompetensi dengan hasil memusaskan, meskipun pada tahap awalnya masih dibimbing oleh guru.

Penelitian tindakan kelas yang dilakukan peneliti yaitu menggunakan metode demonstrasi dan resitasi sebagai upaya untuk meningkatkan prestasi belajar siswa. Dalam penerapan kedua metode tersebut yakni metode demonstrasi dan resitasi mendapat hasil yang cukup memuaskan meskipun terdapat kekurangan dan sedikit hambatan. Namun dapat dijadikan instropeksi untuk kedepan bagaimana belajar mengajar yang lebih baik serta siswa dapat memahami pelajaran yang telah disampaikan oleh guru. Sistem penilaian dari hasil pembelajaran pada kelas 2 diambil dari Uji kompetensi yang meliputi tugas mengerjakan LKS ,Ulangan Harian dan Uji 
praktek, serta dari aktifitas yang meliputi kemampuan dalam bertanya dan antusias dalam pembelajaran. Dari fenomena ini peneliti berinisiatif untuk lebih menekankan siswa terhadap resitasi dan demonstrasi, hal ini diharapkan supaya siswa dapat memahami pelajaran lebih detail dan dapat diterapkan sehari-hari yang dapat berguna bagi dirinya sendiri, dengan demikian siswa juga akan lebih mudah untuk memahami materi Fiqih. Setelah peneliti menerapkan metode Demonstrasi dan metode pemberian tugas (resitasi) dalam mata pelajaran fiqih pada siswa kelas 2 terlihat adanya motivasi tersendiri bagi minat para siswa untuk belajar. Hal ini bisa kita lihat dari hasil nilai yang mereka peroleh setelah menggunakan metode demonstrasi dan metode pemberian tugas (resitasi).

Indikasi lain yakni munculnya suatu kondisi yang menyenangkan pada saat proses belajar mengajar khususnya pada saat demonstrasi. Dari sisni kita bisa mlihat keaktifan metode demonstrasi dan pemberian tugas (resitasi) dalam upaya meningkatkan motivasi belajar siswa.Namun tidak dapat dipungkiri ada beberapa siswa yang tidak terpengaruh dengan adanya metode-metode tersebut, yakni ketika demonstrasi dilaksanakan, ada yang ogah-ogahan karena pada tahap ada yang ogah-ogahan karena pada tahap pertama saja ketika disuruh menghafal belum bisa dikarenakan mereka belum bisa lancar membaca al-qur'an, Sehingga peneliti tidak bisa membedakan siswa-siswa yang aktif dan pasif dalam menghafal Untuk mengatasi permasalahan tersebut, peneliti memberikan waktu lebih kepada siswa untuk menghafal yang kemudian disetorkan diluar jam pelajaran, dan selain itu peneliti juga melakukan pengamatan pada fase mempertangung jawabkan tugas, karena pada fase ini bisa terlihat antar siswa yang benar-benar mengerjakan tugas dan menguasai materi. Dengan metode Demonstrasi dan pemberian tugas (resitasi), kreatifitas, kemandirian dan tanggung jawab siswa terhadap kegiatan belajarnya semakin brkembang, karena sesungguhnya belajar adalah "proses perubahan" yang terjadi dalam diri anak didik setelah berahirnya melakukan aktifitas belajar.

\section{Simpulan}

Berdasarkan penelitian yang telah dilakukan dapat di simpulkan (1) Untuk meningkatkan motivasi belajar dan memahamkan siswa dalam materi menggunakan metode demonstrasi dan metode pemberian tugas (resitasi), (2) Metode demonstrasi dan resitasi merupakan metode yang dapat diterapkan untuk mningkatkan pemahaman siswa dalam mengasai pembelajaran fiqih yang selanjutnya dapat diterapkan dalam kehidupan sehari-hari, (3) Respon atau minat siswa terhadap mata pelajaran fiqih dapat dirangsang dengan cerita yang memupuk kesadaran yang berhubungan dengan materi dan dengan mendemonstrasikan materi skaligus memberikan resitasi berupa LKS dan skema tentang materi yang telah diajarkan. 
Saran bagi peneliti lebih lanjut untuk menggunakan metode yang lebih bervariatif yang dapat mendukung ketercapaian motivasi dan prestasi belajar siswa di tingkan Madrasah Ibtidaiyah

\section{Daftar Rujukan}

Darajat, Zakiyah, (2000) Guru Dan Anak Didik Dalam Interaktif Edukatif, Jakarta PT. Rieneka Cipta

Pasaribu, (1986) Detaktik dan Metodik. Bandung : Tarsito

Sanjaya, Wina, (2016). Penelitian Tindakan Kelas. Jakarta : Prenada Media.

Nana Sudjana, (1984). Dasar-dasar Proses Belajar Mengajar, Bandung : Sinar Baru Algensindo

Usman, Moh Uzer, (1992) Menjadi Guru Profesional, Bandung : Remaja Rosda Karya Zuhairini, (1983) Metode Khusus Pendidikan Agama, Surabaya : Biro ilmiah 